\title{
Studies on some Physico-chemical Parameters of Cyanophycean Members and Correlation Coefficient of Eutrophic ponds in Chidambaram, Tamil Nadu, India
}

\author{
B. Elayaraj, M. Selvaraju* \\ Environmental Science, Department of Botany, Annamalai University, \\ Annamalai Nagar - 608 002, Tamil Nadu, India \\ *E-mail address: dr.mselvaraju66@gmail.com
}

\begin{abstract}
The present study deals with the statistical analysis of physico-chemical parameters and cyanophycean members of two pond water quality of Chidambaram, Cuddalore district (Tamil Nadu). The qualities of pond water were analyzed for six months. Eleven important parameters were included in statistical analysis. The qualities of pond water have been assessed by calculating mean, standard deviation and correlation coefficient. Correlation studies of hydrobiology with physico-chemical parameters revealed that the relationship between phytoplankton density in general and that of the specific groups are highly complex and often controlled by interactions of different factors. In the both pond water the correlation coefficient test revealed that cyanophycean members positively correlated with temperature, $\mathrm{pH}, \mathrm{CO}_{2}$, alkalinity, hardness, nitrate, $\mathrm{BOD}$ and $\mathrm{COD}$ at $1 \%$ and $5 \%$ level significant, where as it is negatively correlated with acidity and dissolved oxygen. In the present study it can be concluded that the cyanophycean members are highly tolerant organisms. They prefer to grow at higher temperatures and in highly alkaline, BOD and COD waters. Hence they can with stand high levels of contaminated waters of Thillai Kali Kovil pond, when compared to Ilamiyakkinar Kovil pond.
\end{abstract}

Keywords: Physico-chemical parameters; Correlation; Phytoplankton; $\mathrm{pH}$; BOD and COD

\section{INTRODUCTION}

Water is one of the abundantly available substances in nature, which man has exploited more than any other resources for the sustenance of life. Water of good quality is required for living organisms. Ponds have been used since time immemorial as a traditional source of water supply in India. However, the water of the ponds, lakes and river are polluted mainly due to discharged waste water from residential areas, sewage outlets, solid wastes, detergents, automobile oil wastes, fishing facilities and agricultural pesticides from farmlands (Srivastava et al., 2003; Usha et al., 2006; Hasan et al., 2007). In some developing countries they are contributing source of water for domestic use such as washing clothes, bathing and sometimes as a source of drinking water (Chia et al., 2009). Phytoplankton represents more comprehensive biological index of the environmental conditions. 
Phytoplankton responds immediately to the surrounding changes and it indicates the water quality and studies on the primary productivity in Indian lentic systems are meager. Biological production in any aquatic body gives direct correlation with its physico-chemical parameters which can be used as trophic status. High rates of production both in natural and cultural ecosystems occur when physico-chemical factors are in favourable conditions (Rueda et al., 2002).

The study of existence and the magnitude and direction of the relation between two are more variables is called as correlation. The correlation helps to determine the degree of relationship between two or more variables. The degree of correlation is also called as correlation coefficient. The present investigation have been undertaken to study the physicochemical characteristics and the presence of cyanophycean members.

\section{MATERIALS AND METHODS}

\section{Study area}

The water samples were collected from two selected ponds Ilamiyakkinar Kovil pond (Pond I) and Thillai Kali Kovil pond (Pond II) which is present in Chidambaram taluk, for a period of six months during the year November 2013 - April-2014.

\section{Sampling methods and analysis of water quality parameters:}

Water samples were collected in polyethylene bottles at different depths. The samples were collected monthly, in intervals between 8.00 am to 10.00 am during the day time. Care was taken to prevent undue shaking of the samples and against sunlight while transporting them to the laboratory. Samples for the estimation of dissolved oxygen and BOD were collected and fixed immediately at sampling site. From each of the sampling site water samples were collected in two litre dark plastic carbouys, washed and rinsed with distilled water. Separate samples were collected for chemical and biological analysis, since the sampling and preservation techniques were quite different. Temperature, $\mathrm{pH}$ and free carbon dioxide were determined immediately at the sampling station. Other samples were taken to the laboratory as early as possible and kept for further analyses were measured by the Procedure given by APHA, 1998.

\section{Sampling of Phytoplankton Analysis and Preservation}

Phytoplankton samples were collected by mesh plankton net (mouth diameter $0.35 \mathrm{~m}$ ) made up of bolting silk (no. 30; mesh size $20 \mu \mathrm{m}$ ) for half an hour. The phytoplankton samples collected were immediately preserved in $4 \%$ formalin and Lugol's iodine solution (Welch, 1980). One $\mathrm{ml}$ of Lugol's solution was added per $100 \mathrm{ml}$ of sample. Lugol's solution sediments phytoplankton stains them and hence easily distinguished under microscope. Identification of species was done using a Nikon Eclipse light microscope. The samples were collected at an interval of 30 days from November 2013 - April 2014.

\section{Statistical analysis}

The correlation between physico-chemical parameters of water samples were analyzed statistically conducting Pearson correlation analysis with the help of SPSS software (16.0). 


\section{RESULTS AND DISCUSSION}

\section{Physico-chemical analysis}

The analytical methods were used to measure the physico-chemical parameters in the water samples collected from the study area between November 2013 - April 2014. The monthly variations of physico-chemical parameters are given in the Table 1 . The correlation coefficient are given in the Table 2.

Table 1. Monthly Variations in physico-chemical parameters of Cyanophycean members of Eutrophic Ponds.

\begin{tabular}{|c|c|c|c|c|c|c|c|c|c|c|c|c|c|}
\hline \multirow{3}{*}{$\begin{array}{l}\dot{z} \\
\dot{s}\end{array}$} & \multirow{3}{*}{ 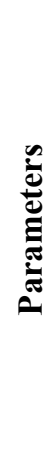 } & \multicolumn{12}{|c|}{ MONTHS 2013-2014 } \\
\hline & & \multicolumn{2}{|c|}{ 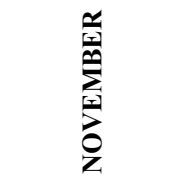 } & \multicolumn{2}{|c|}{ 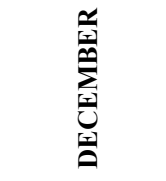 } & \multicolumn{2}{|c|}{ 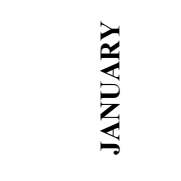 } & \multicolumn{2}{|c|}{ 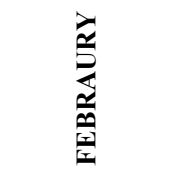 } & \multicolumn{2}{|c|}{$\begin{array}{l}\text { J̃ } \\
\frac{\pi}{\Delta} \\
\Sigma\end{array}$} & \multicolumn{2}{|c|}{$\frac{\vec{z}}{\frac{\pi}{4}}$} \\
\hline & & $\bar{E}$ & 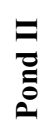 & $\bar{\Xi}$ & $\begin{array}{l}\Xi \\
\Xi \\
\Xi\end{array}$ & 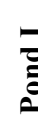 & 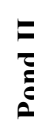 & $\bar{\Xi}$ & $\begin{array}{l}\Xi \\
\Xi \\
\Xi\end{array}$ & $\bar{\Xi}$ & $\begin{array}{l}\Xi \\
\Xi \\
0\end{array}$ & $\bar{\Xi}$ & 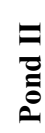 \\
\hline 1 & 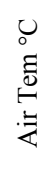 & $\begin{array}{l}\vec{n} \\
\infty \\
0 \\
+ \\
\stackrel{+}{0} \\
\stackrel{\sim}{N}\end{array}$ & 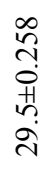 & 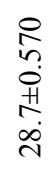 & 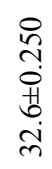 & 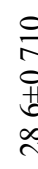 & 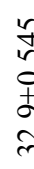 & $\begin{array}{l}2 \\
0 \\
0 \\
0 \\
+1 \\
\text { ஸे } \\
0\end{array}$ & $\begin{array}{l}\vec{\sigma} \\
0 \\
0 \\
0 \\
0 \\
\infty \\
m\end{array}$ & 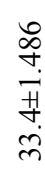 & $\begin{array}{l}\text { 市 } \\
\dot{0} \\
\dot{+1} \\
\dot{D} \\
\dot{m}\end{array}$ & 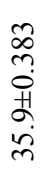 & $\begin{array}{l}0 \\
\stackrel{1}{0} \\
+ \\
+ \\
\text { in }\end{array}$ \\
\hline 2 & 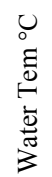 & 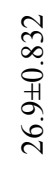 & 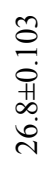 & 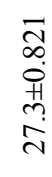 & 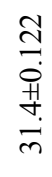 & 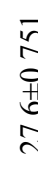 & 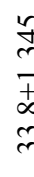 & $\begin{array}{l}\hat{0} \\
\hat{0} \\
0 \\
\text { 11 } \\
\infty \\
\stackrel{i}{1}\end{array}$ & $\begin{array}{l}\vec{D} \\
\infty \\
0 \\
\stackrel{H}{0} \\
\dot{m} \\
\dot{m}\end{array}$ & $\begin{array}{l}\infty \\
\stackrel{2}{0} \\
0 \\
+1 \\
\text { ci } \\
m\end{array}$ & $\begin{array}{l}\infty \\
n \\
0 \\
0 \\
n \\
n \\
n\end{array}$ & 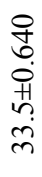 & 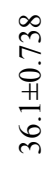 \\
\hline 3 & 壱 & 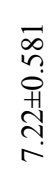 & $\begin{array}{l}\text { Î } \\
\stackrel{0}{0} \\
\stackrel{+}{r}\end{array}$ & 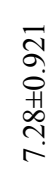 & 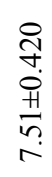 & $\begin{array}{l}\infty \\
2 \\
0 \\
0 \\
\text { ra } \\
r\end{array}$ & 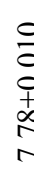 & 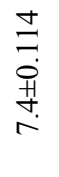 & 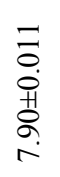 & $\begin{array}{l}\infty \\
\stackrel{2}{0} \\
0 \\
+0 \\
+ \\
\end{array}$ & $\begin{array}{l}0 \\
\infty \\
0 \\
0 \\
0 \\
+1 \\
0 \\
0\end{array}$ & $\begin{array}{l}\hat{2} \\
\stackrel{0}{0} \\
\text { 1 } \\
0 \\
\infty\end{array}$ & $\begin{array}{l}n \\
0 \\
0 \\
+1 \\
0 \\
\infty \\
\infty\end{array}$ \\
\hline 4 & 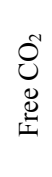 & 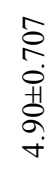 & $\begin{array}{l}\stackrel{0}{2} \\
\stackrel{2}{\circ} \\
\text { 웅 } \\
\dot{+}\end{array}$ & 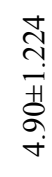 & $\begin{array}{l}\hat{\delta} \\
+ \\
+ \\
+1 \\
\stackrel{+}{0} \\
\dot{+}\end{array}$ & 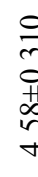 & 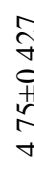 & 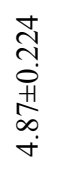 & 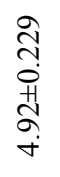 & \begin{tabular}{l}
\multirow{2}{*}{} \\
0 \\
+1 \\
$\infty$ \\
+
\end{tabular} & $\begin{array}{l}0 \\
0 \\
\dot{0} \\
\ddot{1} \\
\tilde{\sigma} \\
\dot{n}\end{array}$ & 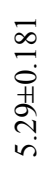 & $\begin{array}{l}\text { ठे } \\
\text { + } \\
\text { मे } \\
\text { Dे } \\
\text { in }\end{array}$ \\
\hline 5 & ภ̊ & 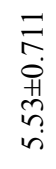 & 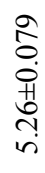 & $\begin{array}{l}\text { ठे } \\
\text { ò } \\
\text { y } \\
\text { in }\end{array}$ & 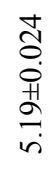 & 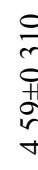 & $\begin{array}{l}0 \\
c \\
c \\
c \\
c \\
c\end{array}$ & 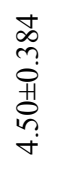 & 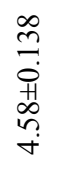 & $\begin{array}{l}\tilde{b} \\
0 \\
\dot{0} \\
\ddot{n} \\
\text { r }\end{array}$ & 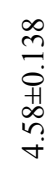 & 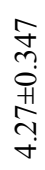 & 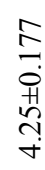 \\
\hline 6 & 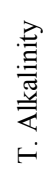 & 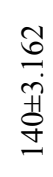 & 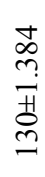 & $\begin{array}{l}n \\
0 \\
\dot{0} \\
+1 \\
n \\
n\end{array}$ & 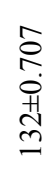 & $\frac{\infty}{2}$ & f & $\begin{array}{l}\tilde{n} \\
\tilde{n} \\
\tilde{n} \\
\tilde{n} \\
\end{array}$ & $\begin{array}{l}\stackrel{n}{a} \\
\widehat{a} \\
\sim \\
0 \\
\infty \\
\infty\end{array}$ & $\begin{array}{l}\text { aे } \\
\text { in } \\
\text { t } \\
\text { I }\end{array}$ & $\begin{array}{l}\frac{J}{7} \\
\frac{H}{6} \\
\frac{6}{6}\end{array}$ & 守 & 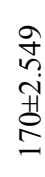 \\
\hline
\end{tabular}




\begin{tabular}{|c|c|c|c|c|c|c|c|c|c|c|c|c|c|}
\hline 7 & 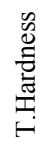 & 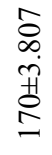 & 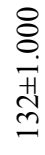 & 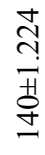 & $\begin{array}{l}n \\
\sigma \\
i \\
\stackrel{n}{n} \\
=\end{array}$ & 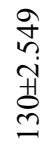 & 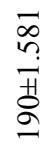 & $\begin{array}{l}n \\
0 \\
0 \\
+1 \\
0 \\
0\end{array}$ & 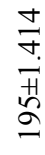 & $\begin{array}{l}\text { aे } \\
\text { in } \\
\text { tै } \\
\stackrel{0}{-}\end{array}$ & $\begin{array}{l}\vec{\infty} \\
n \\
\stackrel{+}{+} \\
\stackrel{+}{+}\end{array}$ & $\begin{array}{l}\tilde{n} \\
\hat{n} \\
\tilde{n} \\
\stackrel{\sim}{0}\end{array}$ & 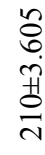 \\
\hline 8 & $\begin{array}{l}\frac{\tilde{\pi}}{0} \\
\overline{0} \\
\frac{0}{0}\end{array}$ & 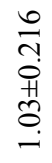 & $\begin{array}{l}\hat{0} \\
0 \\
0 \\
\infty \\
\infty \\
0\end{array}$ & $\begin{array}{l}\text { ते } \\
0 \\
+ \\
\vdots \\
0\end{array}$ & 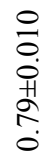 & $\begin{array}{l}\text { ㄱ. } \\
0 \\
+1 \\
\tilde{n} \\
0\end{array}$ & $\begin{array}{l}0 \\
0 \\
0 \\
+1 \\
0 \\
0\end{array}$ & $\begin{array}{l}n \\
0 \\
0 \\
+1 \\
0 \\
0\end{array}$ & 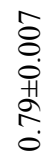 & $\begin{array}{l}\infty \\
0 \\
0 \\
0 \\
\stackrel{0}{0} \\
0\end{array}$ & $\begin{array}{l}n \\
0 \\
0 \\
+1 \\
\infty \\
0\end{array}$ & 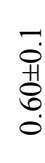 & $\begin{array}{l}\exists \\
0 \\
0 \\
+1 \\
n \\
0\end{array}$ \\
\hline 9 & 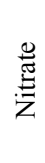 & $\begin{array}{l}\infty \\
0 \\
0 \\
0 \\
+1 \\
0 \\
0 \\
0\end{array}$ & $\begin{array}{l}\text { ठे. } \\
0 \\
\ddot{1} \\
\tilde{\sigma}\end{array}$ & 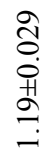 & $\begin{array}{l}n \\
0 \\
0 \\
艹 \\
0 \\
0\end{array}$ & $\begin{array}{l}\text { J } \\
0 \\
0 \\
+1 \\
0 \\
0 \\
0\end{array}$ & $\begin{array}{l}\overrightarrow{0} \\
0 \\
+1 \\
0 \\
0\end{array}$ & $\begin{array}{l}n \\
0 \\
0 \\
+1 \\
n \\
0\end{array}$ & \begin{tabular}{l}
$\infty$ \\
0 \\
0 \\
+ \\
\multirow{H}{*}{} \\
0
\end{tabular} & $\begin{array}{l}0 \\
0 \\
0 \\
n \\
n \\
0\end{array}$ & \begin{tabular}{l}
$\overrightarrow{0}$ \\
+1 \\
\multirow{0}{0}{} \\
0
\end{tabular} & $\begin{array}{l}\text { Tै } \\
0 \\
\text {. } \\
n \\
0\end{array}$ & $\begin{array}{l}n \\
0 \\
0 \\
+1 \\
0 \\
0\end{array}$ \\
\hline 10 & రి & $\begin{array}{l}\infty \\
8 \\
0 \\
\dot{0} \\
+1 \\
0 \\
0\end{array}$ & $\begin{array}{l}0 \\
0 \\
0 \\
0 \\
+ \\
0 \\
0\end{array}$ & 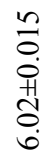 & \begin{tabular}{l}
$\infty$ \\
0 \\
0 \\
0 \\
\multirow{1}{*}{} \\
$\stackrel{0}{0}$
\end{tabular} & 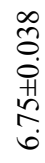 & $\begin{array}{l}\stackrel{\nabla}{0} \\
\ddot{0} \\
\stackrel{+}{0} \\
0 \\
0\end{array}$ & 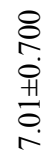 & 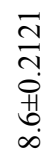 & 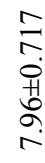 & 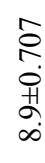 & $\begin{array}{l}\hat{0} \\
\hat{0} \\
01 \\
\stackrel{0}{\circ}\end{array}$ & $\begin{array}{l}\stackrel{\infty}{n} \\
\stackrel{0}{0} \\
\stackrel{+1}{\sigma}\end{array}$ \\
\hline 11 & हิ & $\begin{array}{l}8 \\
8 \\
0 \\
+1 \\
\text { † } \\
\infty\end{array}$ & 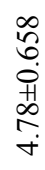 & 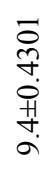 & $\begin{array}{l}8 \\
0 \\
+1 \\
\text { d. } \\
0 \\
0\end{array}$ & $\begin{array}{l}\overrightarrow{0} \\
0 \\
0 \\
0 \\
0 \\
0\end{array}$ & 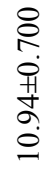 & 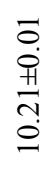 & $\begin{array}{l}\infty \\
\stackrel{2}{0} \\
0 \\
0 \\
\text { ì }\end{array}$ & $\begin{array}{l}\bar{\delta} \\
0 \\
\dot{+} \\
\text { m. } \\
0\end{array}$ & 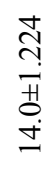 & 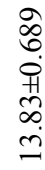 & $\begin{array}{l}\infty \\
0 \\
0 \\
⿱ \\
\tilde{O} \\
\dot{+} \\
\dot{J}\end{array}$ \\
\hline
\end{tabular}

All the values are expressed in $\mathrm{mg} / \mathrm{l}$ except Temperature and $\mathrm{pH}$

Pond I- Ilamiyakkinar Kovil, Pond II- Thillai Kali Kovil pond, Air.tem- Air temperature, Water.tem- Water Temperature, $\mathrm{FCO}_{2}$ - Free Carbon dioxide, $\mathrm{DO}_{2}$ - Dissolved Oxygen, TAlkalinity- Total alkalinity, T.HardnessTotal Hardness, BOD- Biological Oxygen Demand, COD- Chemical Oxygen Demand.

\section{Temperature}

In the present investigation minimum values of air temperature and water temperature ranges from $27.7 \pm 0.851\left({ }^{\circ} \mathrm{C}\right)$ and $26.9 \pm 0.832\left({ }^{\circ} \mathrm{C}\right)$ in Pond-I and $29.5 \pm 0.258\left({ }^{\circ} \mathrm{C}\right)$ and 26.8 $\pm 0.103\left({ }^{\circ} \mathrm{C}\right)$ in Pond II during month of November 2013. Maximum value was recorded 35.9 $\pm 0.383\left({ }^{\circ} \mathrm{C}\right)$ and $33.5 \pm 0.640\left({ }^{\circ} \mathrm{C}\right)$ in Pond-I, $35.4 \pm 0.710\left({ }^{\circ} \mathrm{C}\right)$ and $36.1 \pm 0.738\left({ }^{\circ} \mathrm{C}\right)$ in pond II during the month of April 2014. The temperature values were maximum during summer and minimum during winter. Similar results have been reported by (Jawale and Patil, 2009; Narayana et al., 2008; Anita et al., 2005). Water temperature is very important parameter, because it influences the biota in a water body by affecting activities such as behaviour, respiration and metabolism. It is necessary to study temperature variations in water body, in animals ecophysiological and toxicological aspects because, water density and oxygen content are temperature related and hence temperature indirectly affects osmoregulation and respiration of the animals (De, 2002).

pH

$\mathrm{pH}$ is defined as the intensity of the acidic or basic character of a solution at a given temperature. $\mathrm{pH}$ is the negative logarithm of hydrogen ion concentration $\left(\mathrm{pH}=-\log \left[\mathrm{H}^{+}\right]\right) \cdot \mathrm{pH}$ value ranges from 0 to 7 are diminishingly acidic, whereas values of 7 to 14 are increasingly alkaline. At $25^{\circ} \mathrm{C}, \mathrm{pH} 7.0$ is neutral, where the activities of the hydrogen and hydroxyl ions are equal and it corresponds to $10-7$ moles/L. The neutral point is temperature dependant and 
is $\mathrm{pH} 7.5$ at $0{ }^{\circ} \mathrm{C}$ and $\mathrm{pH} 6.5$ at $60^{\circ} \mathrm{C}$. The maximum value was recorded $8.0 \pm 0.707$ in Pond-I and $8.02 \pm 0.015$ in pond II during the month of April 2014 and minimum value was recorded $7.22 \pm 0.581$ in Pond-I and 7.3 \pm 0.122 in Pond II during month of November 2013. pH value is very important for plankton growth (Chisty, 2002). According to Umavathi et al. (2007) $\mathrm{pH}$ ranged between $5-8.5$ is best for plankton growth.

\section{Free Carbon dioxide $\left(\mathrm{FCO}_{2}\right)$}

Free carbon dioxide in a water body may be derived from the atmospheric sources, biotic respiration, inflowing ground water which seep into the pond, decomposition of organic matter due to bacteria and may also from within the water body itself in combination of other substances mainly calcium, magnesium etc. The present study revealed that minimum value of $\mathrm{FCO}_{2}$ was recorded for the month of January 2014 which was $4.58 \pm 0.310$ $\mathrm{mg} / \mathrm{L}$ in Pond I and the month of November 2013 which was $4.70 \pm 0.736 \mathrm{mg} / \mathrm{L}$ in Pond II. Whereas the maximum value of $\mathrm{FCO}_{2}$ was recorded in the month of April 2014 (5.29 \pm 0.181 $\mathrm{mg} / \mathrm{L}$ in Pond I and $5.04 \pm 0.029 \mathrm{mg} / \mathrm{L}$ in Pond II) during the study period. So, the present study revealed that higher concentration of $\mathrm{FCO}_{2}$ is obtained during the summer season. Free carbon dioxide liberated during respiration and decay of organic matter is highly soluble in natural waters. The carbon dioxide content of water depends upon the water temperature, depth, rate of respiration, decomposition of organic matter, chemical nature of the bottom and geographical features of the terrain surrounding the water body (Sakhare and Joshi, 2002).

\section{Dissolved Oxygen}

Minimum $\mathrm{DO}_{2}$ of water was recorded in the month of April $2014(4.27 \pm 0.347 \mathrm{mg} / \mathrm{L})$ and maximum in December $2013(5.74 \pm 0.029 \mathrm{mg} / \mathrm{L})$ in the Pond I of investigation. In the Pond II the minimum $\mathrm{DO}_{2}$ value was $4.25 \pm 0.177 \mathrm{mg} / \mathrm{L}$ (April 2014) and maximum value of $5.26 \pm 0.079 \mathrm{mg} / \mathrm{L}$ (November 2013) was obtained. TDS analysis has great implications in the control of biological and physical waste water treatment processes. Dissolved oxygen is regarded as one of the best indicator to assess the health of a water body (Jacklin Jemi and Regini Balasingh, 2011).

\section{Total Alkalinity}

Total alkalinity obtained in the minimum and maximum ranges of $129 \pm 1.581 \mathrm{mg} / \mathrm{L}$ (January 2014), $160 \pm 4.472 \mathrm{mg} / \mathrm{L}$ (April 2014) in Pond I and $130 \pm 1.384 \mathrm{mg} / \mathrm{L}$ (November 2013), $170 \pm 2.549 \mathrm{mg} / \mathrm{L}$ (April 2014) in Pond II. Total alkalinity is imparted by presence of bicarbonate, carbonate and hydroxide and less frequently in wetland by borate, silicate and phosphate. The lowest alkalinity was observed during winter and highest during summer due to the decomposition of organic matter in water body Shiddamallayya and Pratima (2008) reported lowest alkalinity during winter. The $\mathrm{CO}_{2}, \mathrm{HCO}_{3}{ }^{-}, \mathrm{CO}_{3}{ }^{2-}$ equilibrium system is the major buffering mechanism in freshwater (Wetzel, 1983).

\section{Total Hardness}

Hardness is due to concentration of alkaline earth metals. $\mathrm{Ca}$ and $\mathrm{Mg}$ ions are the principal cations imparting hardness, it prevents leather forming. $\mathrm{Ca}$ and $\mathrm{Mg}$ are the most abundant elements in natural surface and ground water and exist mainly as carbonates, bicarbonates and carbon dioxide constituted major source of inorganic carbon to producers in an aquatic ecosystem. In the present study, total hardness minimum and maximum ranges of 
$130 \pm 2.549 \mathrm{mg} / \mathrm{L}$ (January 2014), $206 \pm 3.535 \mathrm{mg} / \mathrm{L}$ (April 2014) in Pond I and $132 \pm 1.000$ $\mathrm{mg} / \mathrm{L}$ (November 2013), 210 $3.605 \mathrm{mg} / \mathrm{L}$ (April 2014) in Pond II. The increase in hardness can be attributed to the decrease in water volume and increase in the rate of evaporation at high temperature, high loading organic substances, detergents, chlorides and other pollutants by Rajagopal et al., 2010.

\section{Phosphate and Nitrate}

Present investigations displayed that phosphate obtained in the minimum and maximum range of $0.59 \pm 0.012 \mathrm{mg} / \mathrm{L}$ (January 2014), $1.03 \pm 0.216 \mathrm{mg} / \mathrm{L}$ (November 2013) in the pond I and $0.57 \pm 0.011 \mathrm{mg} / \mathrm{L}$ (April 2014), $0.88 \pm 0.007$ (November 2013) in the Pond II of observation. The most chemically stable form of nitrogen is nitrate. High nitrate concentration can result in excess algal blooms in water body. Fertilizers, decayed vegetables and animal matter are the principle sources of nitrates in a water body. In the present study the minimum and maximum value of nitrate was recorded as $0.51 \pm 0.01 \mathrm{mg} / \mathrm{L}$ (March 2014), $1.19 \pm 0.029 \mathrm{mg} / \mathrm{L}$ (December 2013) in Pond I and $0.37 \pm 0.015 \mathrm{mg} / \mathrm{L}$ (April 2014), 0.65 $\pm 0.015 \mathrm{mg} / \mathrm{L}$ (December 2013) in Pond II. Phosphate and nitrate are considered to be the critical limiting nutrients, causing eutrophication of fresh water systems (Rabalais, 2002).

\section{BOD and COD}

In the present investigation of Pond I the BOD minimum and maximum value ranges $6.02 \pm 0.015 \mathrm{mg} / \mathrm{L}$ (December 2013) and $9.0 \pm 0.707 \mathrm{mg} / \mathrm{L}$ (April 2014). Whereas in the Pond II the minimum and maximum range of the concentration of BOD was $6.04 \pm 0.686 \mathrm{mg} / \mathrm{L}$ (November 2013) and $9.7 \pm 0.707 \mathrm{mg} / \mathrm{L}$ (April 2014). The high COD values indicate that some degree of non-biodegradable oxygen demanding pollutants were present in the water. In the present investigation, the maximum COD value recorded $13.83 \pm 0.689 \mathrm{mg} / \mathrm{L}$ (April 2014) and minimum value of COD obtained was $8.79 \pm 0.700 \mathrm{mg} / \mathrm{L}$ (November 2013) in the Pond I and in the Pond II COD value ranged between $14.03 \pm 0.68 \mathrm{mg} / \mathrm{L}$ (April 2014) to $8.78 \pm 0.658$ $\mathrm{mg} / \mathrm{L}$.

Table 2. Monthly occurrence of Cyanophyceae in Eutrophic ponds of Chidambaram [Or/l].

\begin{tabular}{|c|c|c|c|c|c|c|c|c|c|c|c|c|c|}
\hline \multirow{3}{*}{$\begin{array}{l}\dot{z} \\
\dot{n}\end{array}$} & \multirow{3}{*}{ 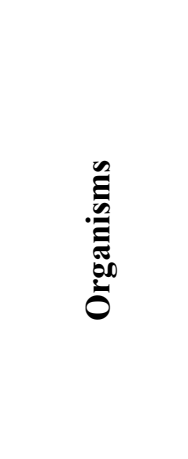 } & \multicolumn{12}{|c|}{ MONTHS 2013-2014 } \\
\hline & & \multicolumn{2}{|c|}{ 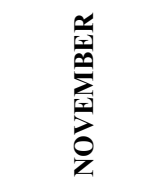 } & \multicolumn{2}{|c|}{ 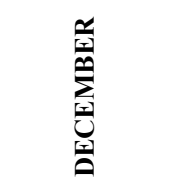 } & \multicolumn{2}{|c|}{ 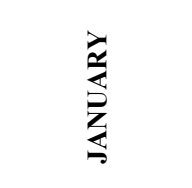 } & \multicolumn{2}{|c|}{ 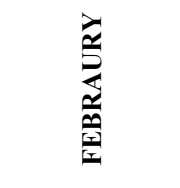 } & \multicolumn{2}{|c|}{ 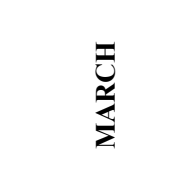 } & \multicolumn{2}{|c|}{ 产 } \\
\hline & & $\bar{\Xi}$ & $\begin{array}{l}\Xi \\
\Xi \\
\Xi \\
\Xi\end{array}$ & $\bar{\Xi}$ & 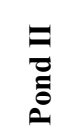 & छ & 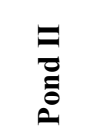 & $\bar{\Xi}$ & 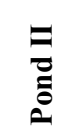 & $\vec{\Xi}$ & 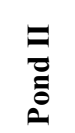 & $\bar{\Xi}$ & $\begin{array}{l}\Xi \\
\Xi \\
\Xi \\
\Xi\end{array}$ \\
\hline 1 & $\begin{array}{c}\text { Anabaena } \\
\text { anomala }\end{array}$ & - & - & 127 & - & 1272 & - & 1685 & 360 & 1624 & 685 & 1864 & 1164 \\
\hline 2 & $\begin{array}{c}\text { Arthrospira } \\
\text { platensis }\end{array}$ & - & - & - & 920 & 558 & 1274 & 495 & 420 & 882 & - & 855 & 840 \\
\hline
\end{tabular}




\begin{tabular}{|c|c|c|c|c|c|c|c|c|c|c|c|c|c|}
\hline 3 & $\begin{array}{l}\text { Coelosphaeri } \\
\text { umdubium }\end{array}$ & 1238 & 1204 & 1783 & - & - & - & - & 520 & - & - & - & - \\
\hline 4 & $\begin{array}{c}\text { Gomphosphaeri } \\
\text { alacustris }\end{array}$ & - & - & - & - & - & - & - & 262 & - & - & - & - \\
\hline 5 & $\begin{array}{c}\text { Microcystis } \\
\text { aeruginosa }\end{array}$ & - & - & - & - & 1726 & - & 1243 & 1674 & 1678 & 1760 & 2305 & 1837 \\
\hline 6 & $\begin{array}{l}\text { Merismopedia } \\
\text { tennusima }\end{array}$ & 775 & 680 & 825 & - & - & 483 & 240 & - & 436 & - & - & 423 \\
\hline 7 & Spirulina major & - & - & - & 1897 & 671 & 1500 & 304 & 210 & - & 970 & - & 580 \\
\hline 8 & $\begin{array}{c}\text { Merismopedia } \\
\text { convolute }\end{array}$ & 112 & - & - & - & - & - & - & 353 & - & - & - & 281 \\
\hline 9 & $\begin{array}{l}\text { Oscillatoria } \\
\text { laeteriraus }\end{array}$ & - & - & - & 363 & 223 & 421 & - & 230 & - & 455 & - & - \\
\hline 10 & $\begin{array}{c}\text { Oscillatoria } \\
\text { acuminate }\end{array}$ & - & - & 165 & - & - & - & 567 & - & 470 & 321 & 1066 & 472 \\
\hline 11 & $\begin{array}{c}\text { Oscillatoria } \\
\text { curviceps }\end{array}$ & 1125 & 1076 & 638 & - & - & 332 & - & - & - & 162 & - & 350 \\
\hline 12 & $\begin{array}{c}\text { Oscillatoria } \\
\text { chilkensis }\end{array}$ & 110 & - & 77 & - & - & - & - & - & - & - & - & - \\
\hline 13 & $\begin{array}{l}\text { Nostoc } \\
\text { calcicola }\end{array}$ & - & - & - & - & - & - & 286 & 161 & - & 210 & - & - \\
\hline 14 & $\begin{array}{l}\text { Rivularia } \\
\text { aquatic }\end{array}$ & - & - & - & 420 & - & - & - & - & - & - & - & - \\
\hline & $\begin{array}{c}\text { Total } \\
\text { organisms }\end{array}$ & 3360 & 2960 & 3615 & 3600 & 4450 & 4010 & 4820 & 4190 & 5090 & 4563 & 6090 & 5947 \\
\hline
\end{tabular}




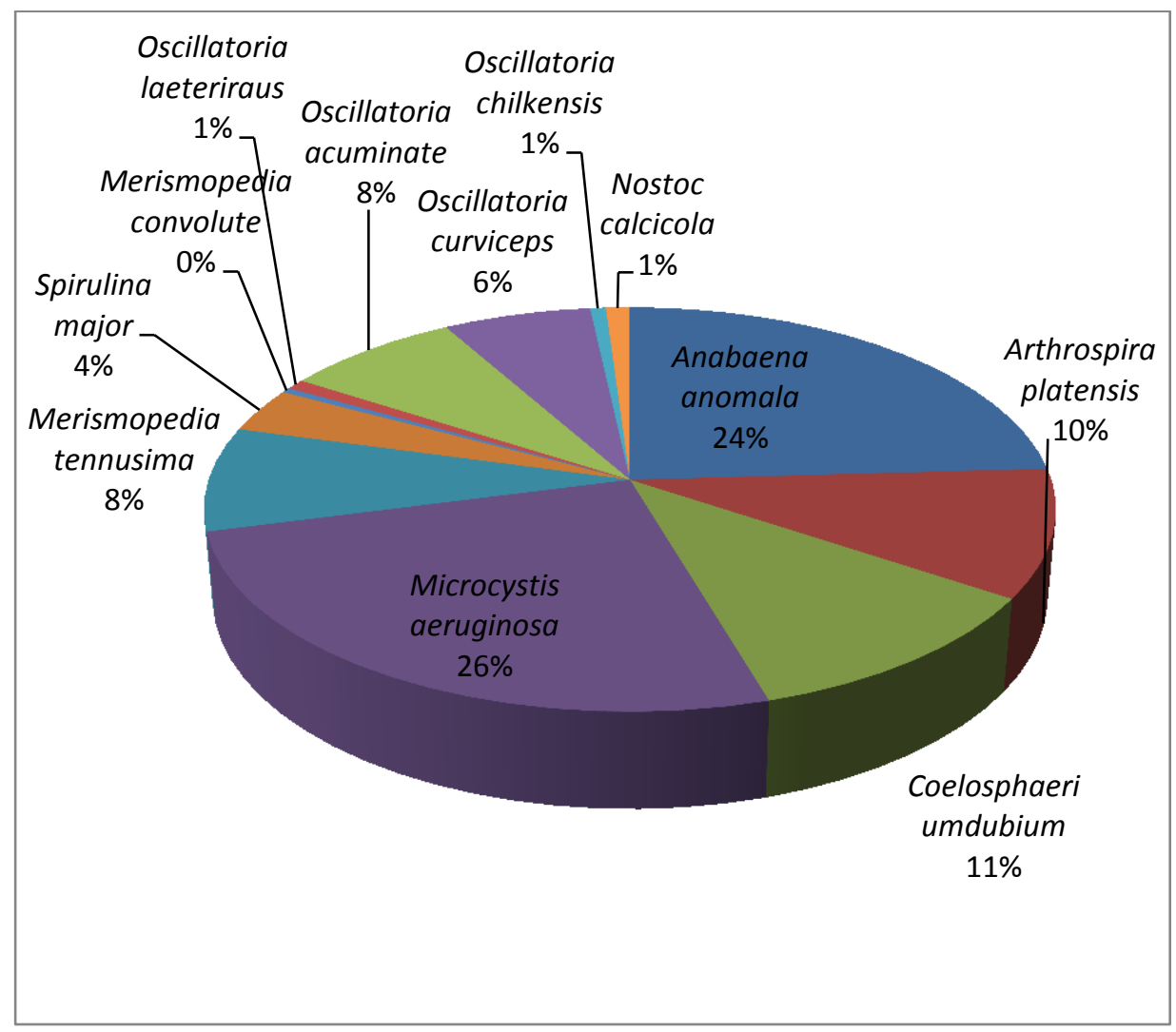

Fig. 1 Percentage of Cyanophycean members in Pond I (Nov 2013 to April 2014).

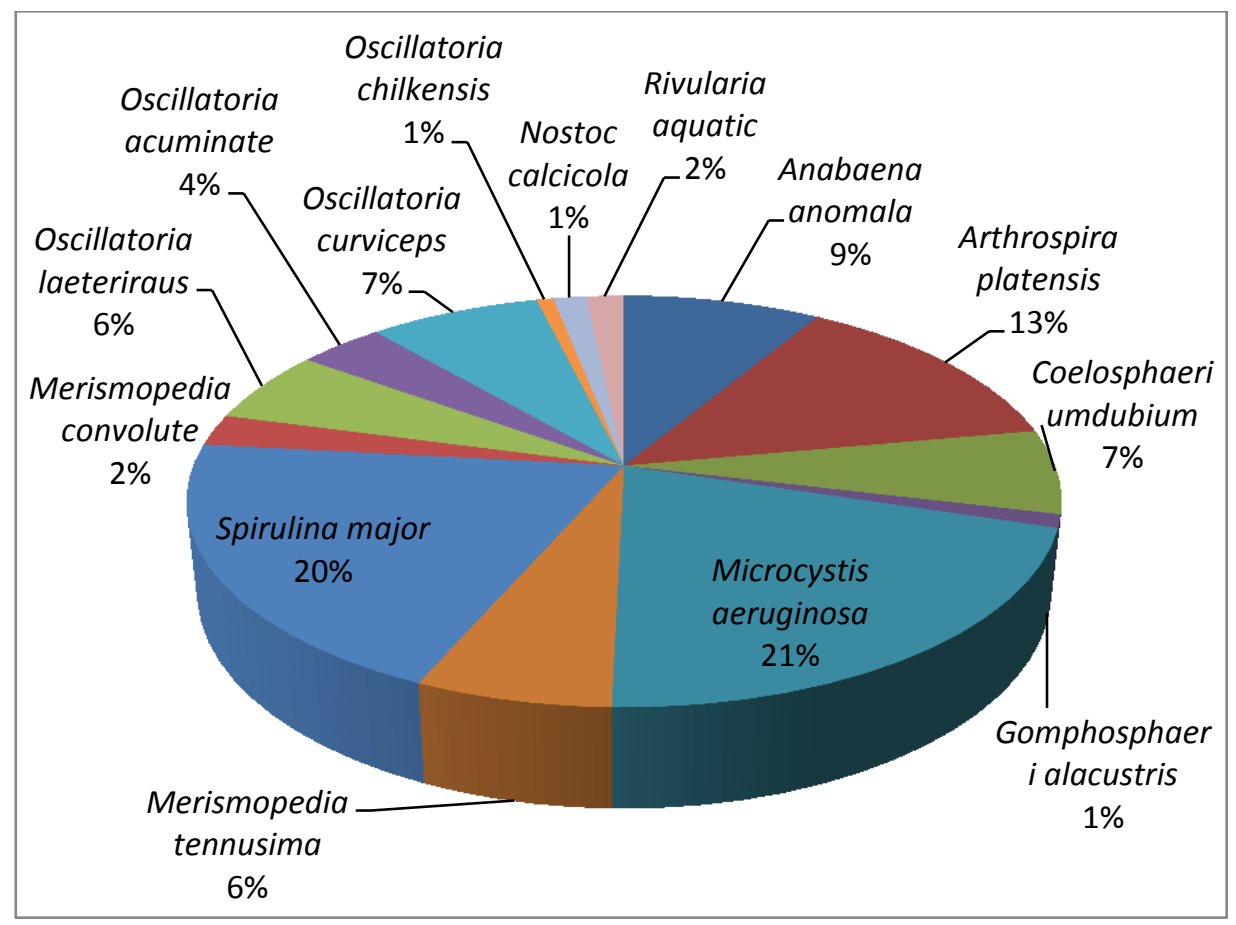

Fig. 2. Percentage of Cyanophycean members in Pond II (Nov 2013 to April 2014). 


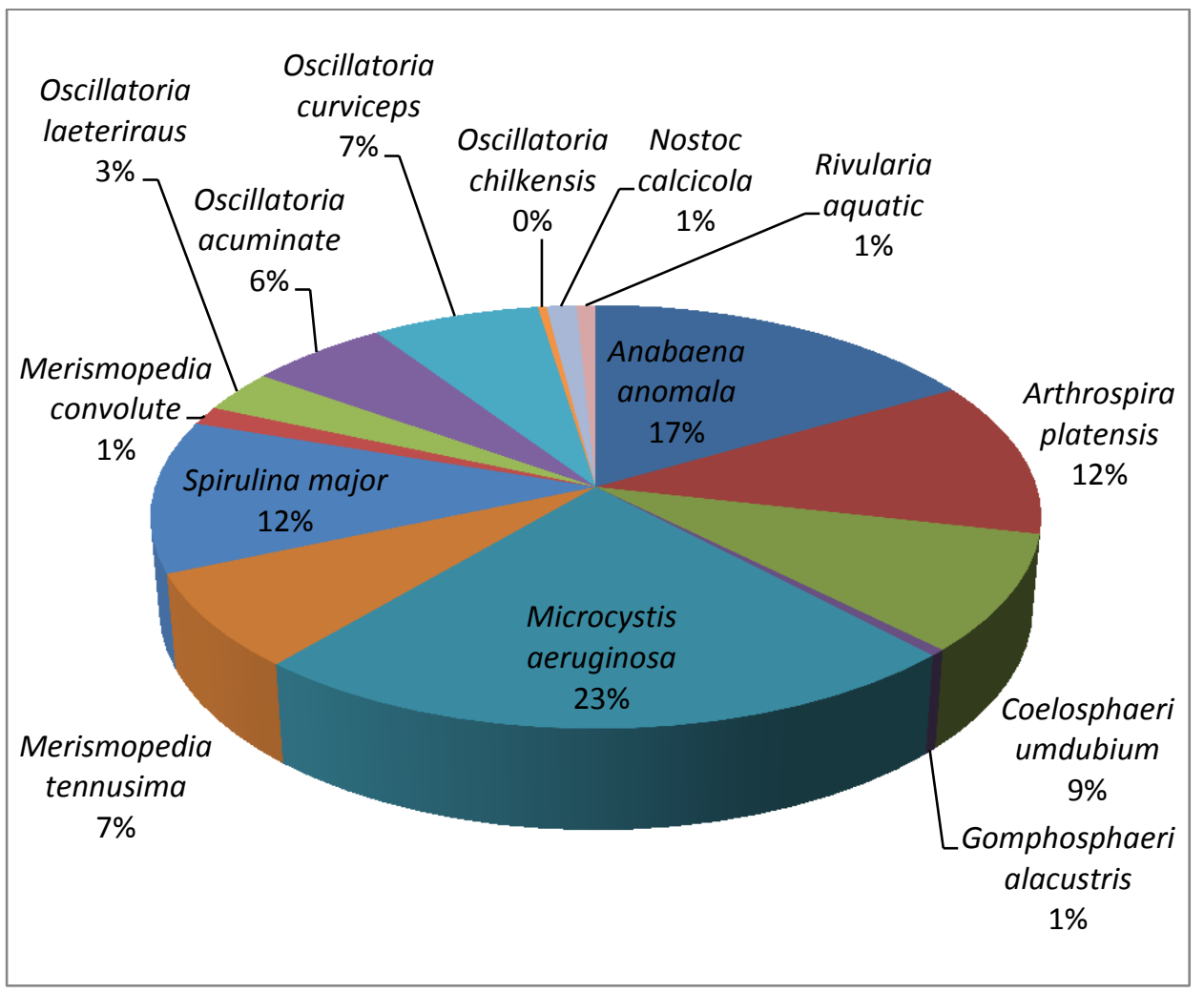

Fig. 3. Percentage of Cyanophycean members in both Ponds (Nov 2013 to April 2014).

(November 2013). BOD is an indication of the organic load and it is a pollution index especially for water bodies receiving organic effluent (Ndimele, 2012).

\section{Cyanophyceae}

Eutrophic ponds contains 14 species of blue green algae. The highest number of Cyanophytes were observed during the month of April 2014 in Pond I (6090 Or/l) and in Pond II (5947 Or/l). The lowest were observed during the month of November 2013 in Pond I (3360 Or/l) and in Pond II (2960 Or/l). During this study period the prominent species were Microcystis aeruginosa, Anabaena anomala, Arthrospira platensis and Oscillatoria acuminate in Fig. $1 \& 2$. Their seasonal occurrence in this water study suggests that their highest growth development was during summer, which gradually decreased during winter season (Table 2). Physico-chemical parameters like $\mathrm{pH}$, dissolved oxygen, phosphate, nitrate, total alkalinity, BOD and COD may have influenced the growth of cyanophyceae. The total percentage of cyanophycean members in Ilamiyakkinar Kovil pond and Thillai Kali Kovil pond is given in Fig. 3. In April 2014 the dominant species were Microcystis aeruginosa (23 \%) [Pond I-2305 (Or/l), Pond II-1837 (Or/l)] and Anabaena anomala (17 \%) [Pond I-1864 (Or/l) Pond II-1164 (Or/l)]. The physico-chemical changes in the water may accept particular species and include the growth and abundance of other species which lead to succession. Low diversity of cyanobacteria was attributed to massive bloom of Microcystis aeruginosa in eutrophic ponds. Microcystis is one of the dominant organism in the present freshwater system. The correlation coefficient of water quality parameters of pond water has been calculated and tabulated in Table 3. In Ilamiyakkinar Kovil pond the simple correlation coefficient test revealed that cyanophycean members positively correlated with air temperature, water temperature, $\mathrm{pH}$, alkalinity, hardness, phosphate, nitrate and $\mathrm{CO}_{2}$ was 
found to be significant at $1 \%$ level where as it was negatively correlated with dissolved oxygen (Table 3.1 ).

Table 3. Correlation Coefficient of Physico-chemical parameters and Cyanophycean members of Eutrophic Ponds November 2013 - April 2014.

Table 3.1. Ilamiyakkinar Kovil Pond (Pond-I)

\begin{tabular}{|c|c|c|c|c|c|c|c|c|c|c|c|c|}
\hline & $\begin{array}{c}\text { Air } \\
\text { temp }\end{array}$ & $\begin{array}{l}\text { Wtr. } \\
\text { Temp }\end{array}$ & pH & $\mathrm{FCO}_{2}$ & $\mathrm{DO}_{2}$ & TA & \begin{tabular}{c|}
$T$. \\
Hard
\end{tabular} & $\mathrm{PO}_{4}$ & $\mathrm{NO}_{3}$ & BOD & COD & CYN \\
\hline Air temp & 1 & $.954^{* *}$ & $.787^{* *}$ & . .547 & $-.829^{* *}$ & $.907^{* *}$ & $.854^{* *}$ & $.883^{* *}$ & $.763^{* *}$ & $.950^{* *}$ & $.834^{* *}$ & $830^{* *}$ \\
\hline \begin{tabular}{|c|} 
Wtr.tem \\
$\mathbf{p}$
\end{tabular} & & 1 & $.855^{* *}$ & .570 & $-.800^{* *}$ & $.966^{* *}$ & $.873^{* *}$ & $.951^{* *}$ & $.871^{* *}$ & $.965^{* *}$ & $.915^{* *}$ & $.922^{* *}$ \\
\hline pH & & & 1 & $.687^{*}$ & $-.820^{* *}$ & $.887^{* *}$ & $.701^{*}$ & $.944^{* *}$ & $.915^{* *}$ & $.831^{* *}$ & $.759^{* *}$ & $.932^{* *}$ \\
\hline $\mathrm{FCO}_{2}$ & & & & 1 & $-.799^{* *}$ & .514 & .422 & $.633^{*}$ & .561 & $.652^{*}$ & .410 & $.606^{*}$ \\
\hline $\mathrm{DO}_{2}$ & & & & & 1 & $-.751^{* *}$ & $-.652^{*}$ & $-.823^{* *}$ & $-.746^{* *}$ & $-.865^{* *}$ & $-.585^{*}$ & $-.779^{* *}$ \\
\hline TA & & & & & & 1 & $.846^{* *}$ & $.955^{* *}$ & $.914^{* *}$ & $.921^{* *}$ & $.930^{* *}$ & $.964^{* *}$ \\
\hline T. Hard & & & & & & & 1 & $.824^{* *}$ & $.650^{*}$ & $.888^{* *}$ & $.891^{* *}$ & $.833^{* *}$ \\
\hline $\mathrm{PO}_{4}$ & & & & & & & & 1 & $.922^{* *}$ & $.936^{* *}$ & $.890^{* *}$ & $.964^{* *}$ \\
\hline $\mathrm{NO}_{3}$ & & & & & & & & & 1 & $.810^{* *}$ & $.819^{* *}$ & $.902^{* *}$ \\
\hline BOD & & & & & & & & & & 1 & $.892^{* *}$ & $.902^{* *}$ \\
\hline COD & & & & & & & & & & & 1 & $.885^{* *}$ \\
\hline CYN & & & & & & & & & & & & 1 \\
\hline
\end{tabular}

Table 3.2. Thillai Kali Kovil Pond (Pond-II).

\begin{tabular}{|c|c|c|c|c|c|c|c|c|c|c|c|c|}
\hline & $\begin{array}{c}\text { Air } \\
\text { temp }\end{array}$ & $\begin{array}{l}\text { Wtr. } \\
\text { Temp }\end{array}$ & $\mathbf{p H}$ & $\mathrm{FCO}_{2}$ & $\mathrm{DO}_{2}$ & TA & $\begin{array}{c}\text { T. } \\
\text { Hard }\end{array}$ & $\mathrm{PO}_{4}$ & $\mathrm{NO}_{3}$ & BOD & COD & CYN \\
\hline Air temp & 1 & $.937^{* *}$ & $.894^{* *}$ & $.716^{* *}$ & -.386 & $.890^{* *}$ & $.852^{* *}$ & .097 & $-.622^{*}$ & $.761^{* *}$ & $.804^{* *}$ & $.675^{*}$ \\
\hline $\begin{array}{l}\text { Wtr. } \\
\text { temp }\end{array}$ & & 1 & $.911^{* *}$ & $.878^{* *}$ & -.512 & $.874^{* *}$ & $.926^{* *}$ & .105 & $-.816^{* *}$ & $.910^{* *}$ & $.885^{* *}$ & $.841^{* *}$ \\
\hline pH & & & 1 & $.802^{* *}$ & -.258 & $.954^{* *}$ & $.927^{* *}$ & .173 & $-.752^{* *}$ & $.856^{* *}$ & $.929^{* *}$ & $.758^{* *}$ \\
\hline $\mathrm{FCO}_{2}$ & & & & 1 & -.513 & $.728^{* *}$ & $.886^{* *}$ & .162 & $-.881^{* *}$ & $.893^{* *}$ & $.795^{* *}$ & $.954^{* *}$ \\
\hline $\mathrm{DO}_{2}$ & & & & & 1 & -.107 & -.413 & -.150 & $.623^{*}$ & -.569 & -.262 & -.490 \\
\hline TA & & & & & & 1 & $.860^{* *}$ & .029 & $-.587^{*}$ & $.730^{* *}$ & $.875^{* *}$ & $.698^{*}$ \\
\hline T.Hard & & & & & & & 1 & .389 & $-.866^{* *}$ & $.944^{* *}$ & $.931^{* *}$ & $.916^{* *}$ \\
\hline $\mathrm{PO}_{4}$ & & & & & & & & 1 & -.422 & .368 & .305 & .348 \\
\hline $\mathrm{NO}_{3}$ & & & & & & & & & 1 & $-.971^{* * *}$ & $-.839^{* *}$ & $-.879^{* *}$ \\
\hline BOD & & & & & & & & & & 1 & $.911^{* *}$ & $.902^{* *}$ \\
\hline COD & & & & & & & & & & & 1 & $.793^{* *}$ \\
\hline CYN & & & & & & & & & & & & 1 \\
\hline
\end{tabular}

**. Correlation is significant at the 0.01 level (2-tailed). *. Correlation is significant at the 0.05 level (2-tailed). Air. temp- Air temperature, Wtr. temp- Water Temperature, $\mathrm{FCO}_{2}$ - Free Carbon dioxide, $\mathrm{DO}_{2}$ - Dissolved Oxygen, TA- Total alkalinity, T.Hard-Total Hardness, $\mathrm{PO}_{4}$ - Phosphate, $\mathrm{NO}_{3}$ - Nitrate, BOD- Biological Oxygen Demand, COD- Chemical Oxygen Demand, CYN- Cyanophyceae. 
In Thillai Kali Kovil pond the correlation coefficient test revealed that cyanophycean members positively correlated with temperature, $\mathrm{pH}, \mathrm{CO}_{2}$, alkalinity, hardness, nitrate, $\mathrm{BOD}$ and COD at $1 \%$ and $5 \%$ level significant, where as it negatively correlated with acidity and dissolved oxygen (Table 3.2). The correlation coefficient ( $\mathrm{r}$ ) has a value between +1 and -1 (Muller, 2001). The correlation between the parameters is characterized as strong, when it is having volume in the range of +0.8 to 1.0 and -0.8 to -1 , Moderate when it is having value in the range of +0.5 to 0.8 and -0.5 to -0.8 , weak when it is in the range of +0.0 to 0.5 and -0.0 to 0.5 (Garrels and Christ, 1965). Statistical study of correlation and regression coefficients of the water quality parameters not only helps to assess the overall water quality but also quantify relative concentration of various pollutants in water and provides necessary cue for the implementation of rapid water quality management programmes (Achuthan et al., 2005; Mahajan et al., 2005; Karunakaran et al., 2009).

\section{CONCLUSION}

In the present study, the correlation of eleven physico-chemical parameters of pond water revealed that all the parameters were more or less, correlated to each other. A large number of factors and geological conditions influence the correlation between different pairs of physico-chemical parameters of water samples directly or indirectly. In pond water high average value of COD and BOD indicate pond water is polluted by organic and sewage waste. It can be used only after primary treatment. Correlation studies of hydrobiology with physico-chemical parameters revealed that the relationship between phytoplankton density in general and that of the specific groups are highly complex and often controlled by interactions of different factors. In the present study it can be concluded that the cyanophycean members are highly tolerant organisms. They prefer to grow at higher temperatures and in highly alkaline, BOD and COD waters. Hence they can with stand high levels of contaminated waters of Thillai Kali Kovil pond (Pond II), when compared to Ilamiyakkinar Kovil pond (Pond I).

\section{ACKNOWLEDGEMENT}

The authors are grateful thanks to Head, Department of Botany, Annamalai University, Annamalainagar for providing necessary facilities to carry out this work and University Grants Commission. Grant F. No. 41411/2012 (SR) Dated: 16-07-2012 for funding the project.

\section{References}

[1] Achuthan N.G., I.M. Abdullah, Mahamoud M. F., Journal of Pollution Research 24(1) (2005) 1-6.

[2] Anita G., S.V.A. Chandrasekar, M.S. Kodarkarm, Journal of Pollution Research 3 (2005) 681-687.

[3] APHA, Standard Methods for the Examination of Water and Wastewater, 19th edition. American Water Works Association, Washington, DC (1998).

[4] Chia A.M., S.J. Oniye, Z. Ladan, Z. Lado, A.E. Pila, V.U. Inekwe, J.U. Mmerole, African Journal of Biotechnology 8(22) (2009) 6282-6289. 
[5] Chisty N., Studies on Biodiversity of Freshwater Zooplankton in Relation to Toxicity of selected Heavy Metals. Ph.D. Thesis submitted to M.L Sukhadia University Udaipur, (2002).

[6] De A.K., Environmental Chemistry. 4th ed., New Age International Publication, 2002, New Delhi, pp: 231-232.

[7] Garrels R.M., C.L. Christ, Solution minerals and equilibrium, Harper and Row, New York, (1965), 450.

[8] Hasan G.O., Paul P. Mathisen, Don Pellegrino, J. Environ. Biol. 28 (2007) 493-502.

[9] Jacklin Jemi R., G.S. Regini Balasingh, International J. f Geo., Earth and Environ. Sci. 1(1) (2011) 59-62.

[10] Jawale A.K., S.A. Patil, Journal of Aquatic Biology 24(1) (2009) 7-12.

[11] Karunakaran K., P. Thamilarasu, R. Sharmila, E. J. Chem., 6(3) (2009) 909-914.

[12] Mahajan S.V., S. Khare, V.S. Shrivastava, Indian J. Env. Prot. 25(3) (2005) 254-259.

[13] Muller B. A., Health. Perspt. 109 (2001) 6.

[14] Narayana J., E.T. Puttaiah, D. Basavaraja, J. Aquatic Biolology, 23(1) (2008) 59-63.

[15] Ndimele P.E., J. Environ. Sci. Tech. 5 (2012) 128-136.

[16] Rabalais N., Ambio. 31(2) (2002) 102-112

[17] Rajagopal T., A. Thangamani, S.P. Sevarkodiyone, M. Sekar, G. Archunan, Journal of Environmental Biology. 31 (2010) 265-272.

[18] Rueda, J., A. Camacho, F. Mezquita, R. Hernanadez, J.R. Roca, Journal of Freshwater Biology 13 (2002) 521-544.

[19] Sakhre V.B., P. K. Joshi, J. Aquat. Biol., 18 (2) (2002) 17-22.

[20] Shiddamallayya N., M. Pratima, Journal of Environmental Biology 29(3) (2008) 303-308.

[21] Srivastava N., M. Agrawal, A. Tyagi: J. Environ. Biol. 24 (2003) 177-180.

[22] Umavathi S., K. Longakumar, Subhashini, Journal of ecology and environmental conservation 13(5) (2007) 501-504.

[23] Usha R., K. Ramalingam, U.D. Bharathi Ramjam, J. Environ. Biol. 27 (2006) 713-722.

[24] Wetzel R.G., Limnology, Second Edition, edited by Wetzel L.G., Michigan State University, CRS College Publishing Philadelphia (1983), New York, Chicago. 784. 